\title{
TWO BURLINGTON CHURCHES OCCUPIED
}

Evidently the editors of the formal histories of the Hawkeye state quite generally understood that all the territorial legislative sessions at Burlington were held in the Old Zion Methodist church, as those examined make no reference to any session being housed elsewhere. It has remained for less authoritative historians to come up with research information revealing that St. Paul's Catholic church in Burlington was occupied by the council, or senate as now known, in the extra session of 184041. Two of those more recently disclosing this not widely known fact, were John C. Parish in his article, "Father Mazzuchelli," Palimpsest, Vol. I, No. 4, p. 106; and Kenneth E. Colton's well documented article entitled "Father Mazzuchelli's Iowa Mission," ANNals of Iowa, Vol. XXI, pp. 299-300.

And now renewed interest in the subject has developed in the confirmation of the historic event through Dr. M. M. Hoffman's admirable Centennial novel, "Young and Fair Is Iowa," pp. 122-23, in which tribute is paid to Iowa's pioneers, blending the element of history with that of fiction. Therein the generous impulses and friendly relations characterizing the association of politician, soldier and the cleric is illustrated in the quickness of repartee credited to U. S. Senator Augustus Caesar Dodge and Father Samuel Charles Mazzuchelli', pioneer Catholic missionary of the upper Mississippi valley, at a social

\footnotetext{
1"This extraordinary missioner, the gentle-born Italian Dominican, Samuel Charles Mazzuchelli. To his many admirers... saint, and scholar, architect and artist, priest of God and gentleman of the Iowa frontier, (he) personified physical and spiritual courage; . . . this Italian's tongue was a fire of eloquence. He had arrived in Dubuque... and for several years was the only priest in the wilderness for hundreds of miles in all directions and a thousand miles in some. Half-breeds and traders, miners and landseekers composed his far-flung flock. A trip of hundreds of leagues on foot over ice and snow never dismayed him; the tepees of the savage and the huts of the hard-drinking frontiersman were his home. Precursor of the faith, pathfinder in the wilderness, under his magnetic influence churches and chapels sprang up from Michigan and Wisconsin to Illinois and Iowa. . . . this foreign emissary . . had formed or helped to form every early mission along the river from Dubuque almost to the Missouri state border, and inland as far as Little Maquoketa and Iowa City."- "Young and Fair Is Iowa". pp. 123-4; Hoffman.
} 
gathering in Dubuque where the senator was a guest of honor. The spirited conversation related as having occured there ran thus:

“So you're not living in Iowa any longer," Dodge was saying. "If you don't like Dubuque, come down to Burlington. We treated you well on your past visits there, didn't we, Father?"

"Indeed you did,' said the priest. "I remember the 'boundary war' that threatened to break out between Iowa and Missouri a few years ago, and when you were general of the militia down there how some of your friends in Burlington wanted to make me your army chaplain, but you would have none of me!"

"I remember that well," laughed General Dodge, "but I made honorable amends for that later though, when my friends helped you rent the new St. Paul's church to Iowa Territory to serve temporarily as its capitol. Do you recall that?"

"Oh, yes, that was before the church was blessed," said the priest. "It may be of amusing interest to the gentlemen here to hear about that. I rented the church to the Iowa government for sixty days. We received $\$ 500.00$, and we were able to pay off the church debt. On Sundays when the legislature, of course, was not in session, I celebrated Mass in this 'capitol'; and when I preached, my pulpit was the same desk that was used by the president of the senate. I remember that some of the senators complained that my drinking water was too salty, and when I discovered to my horrified amazement that the Iowa legislators had been drinking during the session the Holy Water in which I had naturally mixed a good quantity of blessed salt!"

... A burst of laughter greeted the missioner's story."

With natural interest the subject of the tenancy of St. Paul's was pursued further, with the result that in the Centennial edition of the Burlington Hawkeye-Gazette, August 2, 1946, Section V, Col. 1, was found under the heading, "Old St. Paul's Built in 1840," the following:

Inseparably, linked with the history of Wisconsin and Iowa territory is the Catholic church in Burlington, this due to the fact that some of the early territorial laws were framed in the first Catholic church erected in Burlington in 1840, Old St. Paul's, situated on the alley in the rear of the lot now occupied by the present St. Paul's church.

Old St. Paul's church ... (Cut of church) ... where one of the Iowa territorial legislatures met for about sixty days. 
In establishing what sessions were held and where, no conflict was disclosed in statement referring to certain four sessions being held in Old Zion, confirming belief that St. Paul's was occupied during the session which commenced on the first Monday in November, 1840. Search of the territorial laws of that session verified this, as included in the acts is Chapter 101, p. 109, reprint p. 91, an appropriation act, in part reading:

Sec. 29. Rev. Samuel Mazzuchelli. To the Reverend Samuel Mazzuchelli, for rent of building occupied in Council (senate), three hundred dollars.

Sec. 30. Trustees of Methodist Episcopal church. To the trustees of the Methodist Episcopal church, for rent to building occupied by the house of representatives, four hundred and fifty dollars.

In response to inquiry Dr. Hoffman wrote that he "once called Mr. Harlan's attention to the St. Paul's church session, but it probably was after he had already prepared his material for his 'History of the People of Iowa' ", saying further, "You are correct in your surmise that St. Paul's was used for the Extra Session of 1840. I found the first reference to this fact in Father Mazzuchelli's 'Memorie Istoriche ed Edificante', printed in Milan, Italy, in 1844. On page 263 appears the following:

The members of the legislature of Iowa were beginning to assemble in Burlington for their annual session of seventy-five days, which that year, 1840, commenced on the first Monday in November, and the Methodist church had been used provisionally for the session of the senate and representatives. Through the kindly interest of a number of his friends among the senators, the Missionary (that is the way Father Mazzuchelli always referred to himself in the volume-in the third person as "the Missionary") arranged that the sessions of the senate (council) should be held in his church, which was not then consecrated to Divine Worship. Such a circumstance proves what has already been affirmed in these Memoirs, that the government of the United States in its action has no regard or predilection for one religion in preference to another.

Aside from the more kindly feeling towards catholicity. as one result of the occupation of our church by the senate of Iowa, another was the contribution of 1,500 franes and other considerable profits given for the rent of sixty days. This contribution added 
to that from the people served to cancel completely the entire debt contracted for erection of the building. During the session of the legislature, on November 22,1840 , the priest preached for the first time in the new church, his pulpit being the same desk that was used by the president of the senate.

This work was translated into English by Sister Mary Benedicta Kennedy, O.S.D., Saint Clara Convent, Sinsinawa, Wisconsin, in 1914, and published in 1915, a copy being on the shelves of the State Historical Library, Des Moines. The translation in entitled "Memoirs, Historical and Edifying, of a Missionary Apostolic," and was the source of Mr. Colton's information a decade ago. Dr. Hoffman says the translator mistakenly used the figure five hundred dollars as rent paid by the Iowa legislature. $\mathrm{He}$, too, used that figure in his historical novel, explaining that "really, according to Father Mazzuchelli's own figures and according to the territorial legislature's records it should have been three hundred dollars; but the rate of exchange at that time, as I understand, was five francs to the dollar, and that would have made the amount three hundred dollars. And so, in my historical study, "The Church Founders of the Northwest: Loras and Cretin, and Other Captains of Christ", (1937), I summed up the matter."

\section{THE POOR MAN'S COLLEGE}

Johnson Brigham: One only has to glance through the biographies of prominent Iowans to find that in many notable instances the printing office proved to be the poor man's college. It issued no diplomas, but it gave to the youths and young men who came under its influence that close touch with community life and the larger life outside, which fitted them for the spheres of influence which they were destined to occupy. 
Copyright of Annals of Iowa is the property of State of Iowa, by \& through the State Historical Society of Iowa and its content may not be copied or emailed to multiple sites or posted to a listserv without the copyright holder's express written permission. However, users may print, download, or email articles for individual use. 